\title{
Diurnal and seasonal variation in defensive behavior of African bees Apis mellifera adansonii in Ghana
}

\author{
J Woyke * \\ FAO Representation, Accra and Technology Consultancy Centre of Kumasi University, Ghana
}

(Received 1 September 1991; accepted 27 April 1992)

\begin{abstract}
Summary - The defense behavior of an African bee colony was studied in order to determine recommendations for handling $A m$ adansonii bees (when and how) without being stung. The number of stings left in a leather ball suspended $50 \mathrm{~cm}$ in front of the hive entrance for $1 \mathrm{~min}$ was therefore counted as well as the number of workers returning to the hive over a 5-min period. A typical pattern of diurnal defensive behavior was observed. During the non-productive period, ie the summer rainy season, one peak of defensive behavior was observed in the morning. During the period of honey flow, ie the winter dry season, 2 peaks occurred, one early in the morning and the other late in the evening. A highly positive correlation existed between flight activity and defensive behavior. The bees stung less during periods of low flight activity. Bees in front of the entrance defended the colony more than those flying out from the combs. During the period of honey flow (the winter dry season), the bees stung about 4 times more frequently than during the summer rainy season. The ratio of the number of stinging bees to that of flying bees is a better indicator for comparison of potential defensive behavior of different colonies than that of the absolute number of stings. It is recommended that handling of $A m$ adansonii take place during periods of low flight activity.
\end{abstract}

Apis mellifera adansonii / defensive behavior / activity rhythm / flight activity / Ghana

\section{INTRODUCTION}

The highly defensive behavior of African bees is well known. It is therefore important to determine the periods during which the bees are more aggressive and those when they are less aggressive. On this basis, suggestions can be made about when and how to work with the bees. The defensive behavior of honey bees in the field has been investigated several times.
To further examine this aspect, the number of stings left in a dark leather ball suspended in front of the hive entrance was counted (Free, 1961; Stort, 1970, 1974, 1975; Brandenburgo et al, 1977; Collins et al, 1982; Collins and Kubasek, 1982; Villa, 1988). The colony defense behavior of Africanized and European honeybees was then compared. A model of honeybee defensive behavior, involving 4 steps, has been presented by Collins et al (1980). Experiences with Africanized bees under

\footnotetext{
* Present address: Bee Division, Agriculture University, SGGW, 166 Nowoursynowska, 02-766 Warsaw, Poland
} 
very different conditions at sites in Brazil and Poland have been described by Woyke (1973). The latter author has pointed out (1989a) that a correlation exists between flight activity and defensive behavior.

During the daily work with bees in Ghana, 3 distinct phenomena concerning the defensive behavior of Apis mellifera adansonir, were observed, ie: 1), wide variation in defensive behavior during the day; 2) when smoke was directed through the hive entrance into the bee nest, worker bees escaped in great numbers and started to sting the beekeeper. The same phenomenon occured when the hive was opened and smoke was directed between the combs; 3), the bees exhibited nonagressive behavior during the nonproductive period, ie the summer rainy season, and were very aggressive during the winter dry season, ie the period of honey flow. Individual discussions as well as those conducted at beekeepers' meetings showed that these phenomena had been noticed and were familiar to many Ghanian beekeepers. Quantitative investigations were therefore conducted to determine whether the daily practical observations could be scientifically confirmed.

\section{MATERIALS AND METHODS}

The study took place in Ghana over a 2-month period (26/5/1986-26/7/1986) during the summer rainy - non-productive season, and over a 3 month period (23/11/1986-21/2/1987) during the winter dry-honey flow season. The author worked with the bees daily for 10-12 h. At different times, 20-30 bee colonies were present at the university apiary in Kumasi. However, bees in other apiaries in north, central and south Ghana were also studied (Woyke, 1989a,b, 1992). Detailed investigations were conducted in Kumasi in central Ghana. The defensive behavior of 4 Apis mellifera adansonii bee colonies was studied. The colonies were kept in Kenya top bar hives placed on individual stands several meters apart.
Investigations were conducted every hour from 6.00 to $18.00 \mathrm{~h}$, ie 13 times a day. The number of worker bees returning to the hive over a 5 -min period was counted (Woyke, 1992). These numbers were divided by 5 to obtain results relating to a 1-min period, which were used for further calculations and comparisons. The defensive behavior of worker bees was then investigated. To this end, a black leather ball (diameter $7 \mathrm{~cm}$ ) was turned with the rough side outside. Before the ball was used for tests, it was placed close to the entrance of a hive (not used in the experiment) to be stung by dozens of workers, so that it became impregnated with the smell of venom. For the test the ball was suspended on a thread $50 \mathrm{~cm}$ in front of the hive entrance, and was set in oscillatory motion for $1 \mathrm{~min}$. Stings that had lodged in the ball were then counted and removed. On February 8th, 2 additional tests were conducted. Immediately after the first test was completed, the ball was suspended for $1 \mathrm{~min} 25 \mathrm{~cm}$ above the top bars of the same colony, while 2 beeways were opened between 3 combs. After the stings had been removed and counted, 2 puffs of smoke originating from burning dry leaves were directed between the 2 opened beeways, and the test was repeated. At the same time, temperature, $\mathrm{RH}$ and degree of cloudiness were noted.

The area occupied by brood was measured in 3 colonies at the time of the investigations. Measurements of natural cells showed, that 5.067 cells occupied an area of $1 \mathrm{~cm}^{2}$. Three colonies were weighed at weekly intervals.

Analysis of variance was performed. Newman-Keuls multiple comparison test was used to determine significant differences between means. $\chi^{2}$ test was used to compare frequency distributions.

\section{RESULTS}

\section{Diurnal pattern of defensive behavior}

A wide variation in diurnal defensive behavior was recorded during the day in different bee colonies: from 2-112 stings over a $1-\mathrm{min}$ period in colony No 5 , to $33-$ 144 stings/min in colony No 3 (both on 
June 23,1986$)$, or 8-248 stings/min in colony No 4 (January 13, 1987).

A characteristic pattern of diurnal defensive behavior was noted. During the dearth period, ie the rainy season (June, 23), defensive behavior of colony No 4 rose from $18 \mathrm{stings} / \mathrm{min}$ at $6 \mathrm{~h}$ to a peak of 62 stings/ min at $9.00 \mathrm{~h}$ (fig 1). Later, the defensive activity declined. Some variation occurred during the day. Low defensive behavior was observed at midday (11 stings/min at $13 \mathrm{~h}$ ), with the lowest activity recorded in the evening (5-6 stings/min at 17.00 and $18.00 \mathrm{~h}$ respectively).

Considerable changes occurred during the period of honey flow, ie the winter dry season (January 13; fig 2). Three peaks of colony defense were recorded. One early morning peak of 107 stings/min occurred at $6 \mathrm{~h}, 30 \mathrm{~min}$ before sunrise. Then, defensive activity dropped to 11 stings/min at $8 \mathrm{~h}$, and reached the highest peak of 248 stings/min at $10 \mathrm{~h}$. Defensive behavior again dropped to 8 stings/min at $14 \mathrm{~h}$, but rose to $163 \mathrm{stings} / \mathrm{min}$ at $18 \mathrm{~h}$ just before sunset. About 1 month later (fig 3), only 2

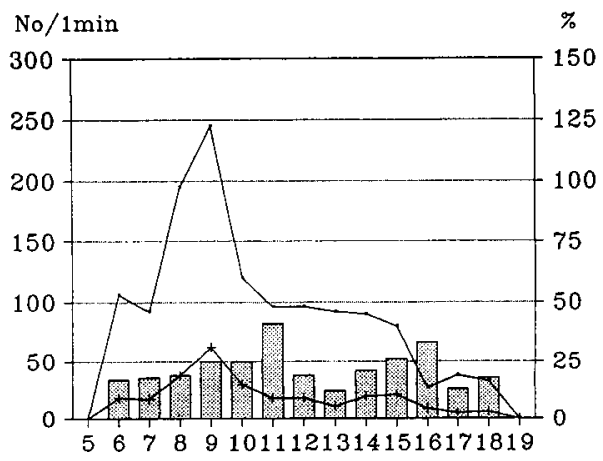

Hours of $t h e d$ a $y$

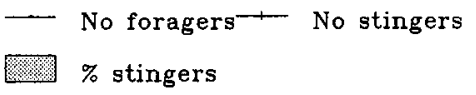

Fig 1. Diurnal colony defense and flight activity of colony No 4 during the dearth-summer rainy season in Kumasi on June 23, 1986.
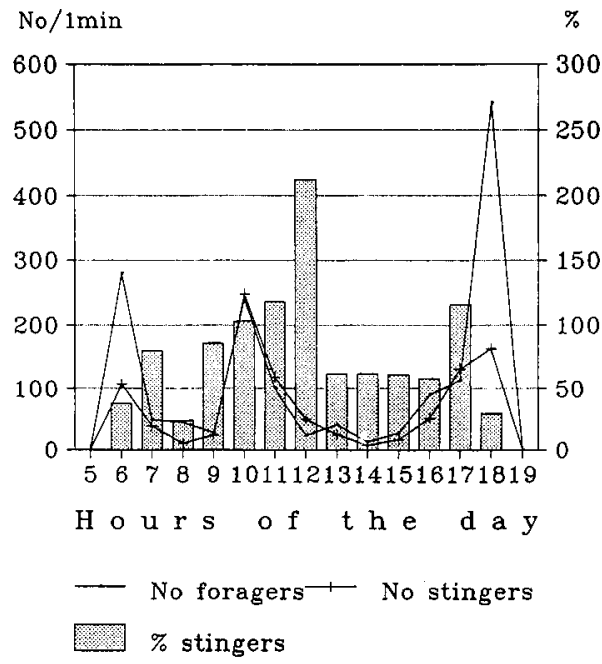

Fig 2. Diurnal colony defense and flight activity of colony No 4 during the honey flow-winter dry season in Kumasi on January 13, 1987.

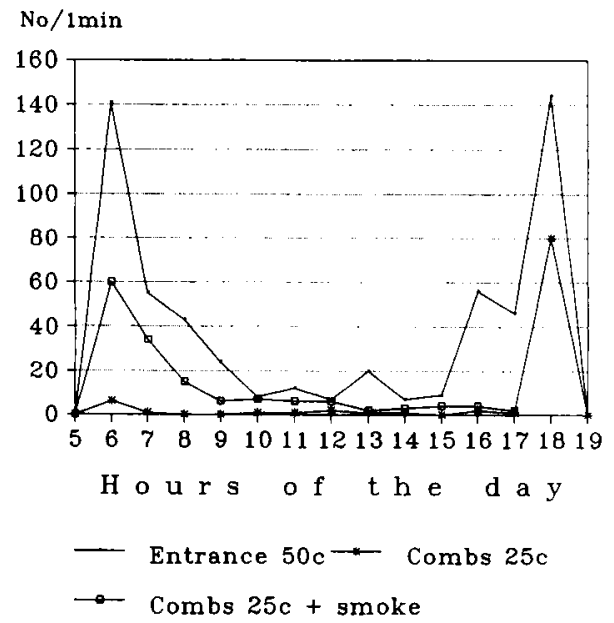

Fig 3. Diurnal stinging of bees from colony No 4 in Kumasi on February 8, 1987 of dark leather ball, suspended $50 \mathrm{~cm}$ in front of the hive entrance (Entrance $50 \mathrm{c}$ ), $25 \mathrm{~cm}$ above top bars of combs with 2 open beeways (Combs 25c), and the same as previously, but after 2 puffs of smoke were applied to beeways between combs (Combs $25 \mathrm{c}+$ smoke) Kumasi, February 8, 1987. 
peaks of defensive activity were recorded, one early in the morning with 141 stings/ $\min$ and the other late in the evening at $18 \mathrm{~h}$, with 144 stings/min just at sunset. During the rest of the day the bees exhibited gentle behavior. The evening peak of colony defense was characteristic for both days during the honey flow season.

\section{Correlation between defensive behavior and flight activity}

Figures 1 and 2 as well as other recorded data show that stinging intensity was related to flight activity. Statistical calculations revealed a significant correlation between stinging and flight activity during the day. The correlation coefficients for colony No 4 were as follows: (df = 11); $r=0.96$ (June 23) or $r=0.66$ (June 24) during the dearth period-summer rainy season; and $r=0.71$ (Jan 13) and $r=0.96$ (February 8) during the honey flow period-winter dry season. The equation for the regression line presented in figure 4 is $y=-3.26+0.24 x(y=$ No stinging bees; $x=$ No of returning for-

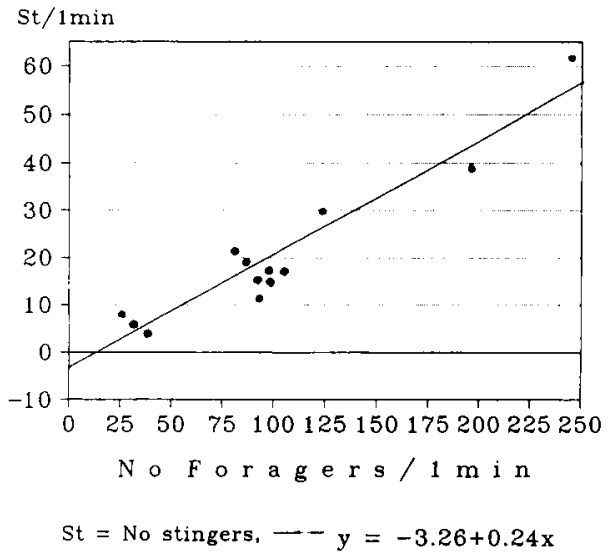

Fig 4. Regression between the number of foragers returning to colony No 4 and number of stings in a dark leather ball at different hours on June 23, 1986. agers/min). The slope as well as the intercept for the other days were different.

The ratio between the number of stinging bees and returning workers was calculated. For easier presentation and assessment, it was multiplied by 100 and called the percentage. This ratio did not remain constant during the day. Bee colony No 4 showed a range of $12-41 \%$ stinging bees during the dearth period-summer rainy season (June 23; fig 1), to 24-212\% during the honey flow period-winter dry season (January 13; fig 2). Thus sometimes only a low percentage of flying bees engaged in stinging activity, but sometimes twice as many bees were stinging as returning to the hive. The other stinging bees were workers flying out of the hive and the guard bees. Figures 1 and 2 show that in general the ratio of stinging bees was highest at midday.

Taken together, the results justify a general prediction: low relative flight activity indicates low defensive behavior, the opposite behavior pattern to that expected with European bees.

\section{Defensive behavior of bees in front of the entrance and of bees flying out of beeways between combs}

Specific tests (fig 3) showed that between 6-17 h, 7-141 workers stung the ball suspended $50 \mathrm{~cm}$ in front of the entrance; however, only 0-6 workers stung a ball suspended $25 \mathrm{~cm}$ above the top bars of 2 opened beeways. Tests were also carried out with a ball suspended $50 \mathrm{~cm}$ above the top bars. However, the bees practically did not sting the ball that was suspended so high. Thus, bees in front the entrance defended the colony more vigorously than those flying out of beeways between the combs. More surprising was the observa- 
tion that as many as $2-60$ bees from beeways between combs stung the ball after they had been smoked out. An especially vigorous reaction to smoking was observed after the first treatments at 6 and $7 \mathrm{~h}$. The bees were also particularly defensive at $18 \mathrm{~h}$ during the period of maximal flight activity. They flew out of the hive not only through the entrance and the 2 opened beeways between combs, but also through all cracks and openings. They attacked everything so vigorously that the smoking test could not be conducted at that time. Between 6-17 h, a total of 428 workers stung the ball in front of the entrance, 16 the ball suspended $25 \mathrm{~cm}$ above the top bars of 2 opened beeways and 149 after the bees had been smoked out with 2 puffs of smoke. The ball in front of the entrance was stung on average $(n=$ 12; $x \pm$ SEM) $35.7 \pm 11.1$ times per test, the ball above the opened beeways $1.3 \pm$ 0.5 times before smoking and $12.4 \pm 5.0$ times after the bees had been smoked out. Paired $t$-test showed a statistically significant difference between the 2 latter means, $t=2.37 ; \mathrm{df}=11 ; P=0.037$. Thus smoking significantly increased the defensive behavior of worker bees. Workers stung the ball on the average 10 times more after than before smoking.

Correlation coefficients between the number of foragers and the number of stingers in front of the entrance, above combs before and after smoking were: $r=$ $0.93, r=0.86$ and $r=0.87$ respectively. Regression between these characters was $y=7.87 \pm 0.47 f, y=0.26+0.02 f$ and $y=$ $0.64+0.20 f \mathrm{~g}$ respectively $(f=$ No foragers). The values of the intercept and the slope for number of stinging bees after the bees had been smoked out were between those for the number of stinging bees in front of the entrance and the number above the combs before the bees had been smoked out. All these results confirm the daily practical observations according to which bees started to sting after the smoke had been directed through the entrance into the bee nest. It can be concluded that the smoke irritated the bees and increased their defensive reaction.

\section{Defensive behavior in different seasons}

Defensive behavior was investigated in summer and winter. The temperature at $14 \mathrm{~h}$ on January 13 was $4^{\circ} \mathrm{C}$ higher, and on February $8,7^{\circ} \mathrm{C}$ higher than in summer, although the early morning temperature on January 13 was the lowest (fig 5). June falls during the non-productive period-summer rainy season. January and February fall during the honey flow periodwinter dry season. The bee colonies lost 1-2 kg/colony/week in June and in January gained $1-1.5 \mathrm{~kg} /$ colony/week. The number of brood combs in colony No 4 on

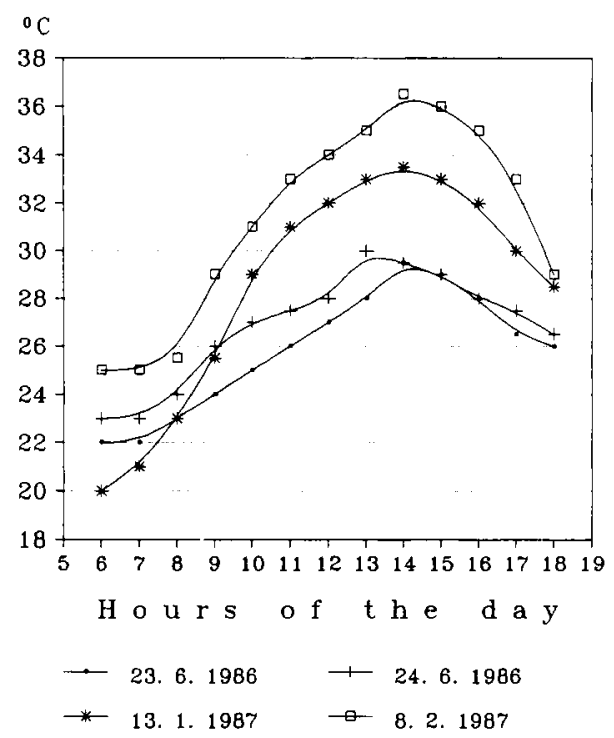

Fig 5. Temperature in Kumasi during the investigation period. 
June 26, January 15 and February 5 was 10,8 and 7 (combs) respectively. The bees covered 4-5 more combs.

Figure 1 shows that one morning peak of defensive behavior was observed on June 23 , during the non-productive period-summer rainy season. A similar pattern in the same colony was noted the next day. Figures 2 and 3 show that at least 2 peaks, one early in the morning and the other late in the evening, were observed during the honey flow periodwinter dry season. Thus the pattern of diurnal defensive behavior of the same colony did not remain constant. It may change drastically during different periods of the year. The 2 patterns of colony defense agreed very well with the 2 patterns of flight activity recorded by Woyke (1992) during 10 different days of investigation in both seasons in Ghana.

The average number of flights/min during the entire day, as well as the average number of stings/min during the day was calculated (fig 6). $\chi^{2}$-Test showed that frequency distribution of the average number of foragers on different days differed significantly from that of the number of brood combs present in the colonies at the same time: $\chi^{2}$ calc $=12.5>\chi^{2}$ tab $0.05=7.81, P=$ $0.006(\mathrm{df}=3)$. Thus the amount of brood (noted above) did not show a correlation with the number of foragers.

Statistical calculations did not show significant differences in the average number of foragers in different seasons, as presented in figure 6 . However, the $\chi^{2}$-test showed that the averages differed from the 1:1:1:1 frequency distribution: $\chi^{2}$ calc $=$ $12.78>\chi^{2}$ tab $0.05=7.81, P=0.006(\mathrm{df}=$ 3). No significant differences were found between both averages of the number of stinging bees in each season. The average number of stinging bees on January 13 was significantly higher than both summer averages. $\chi^{2}$-Test showed that the fre-

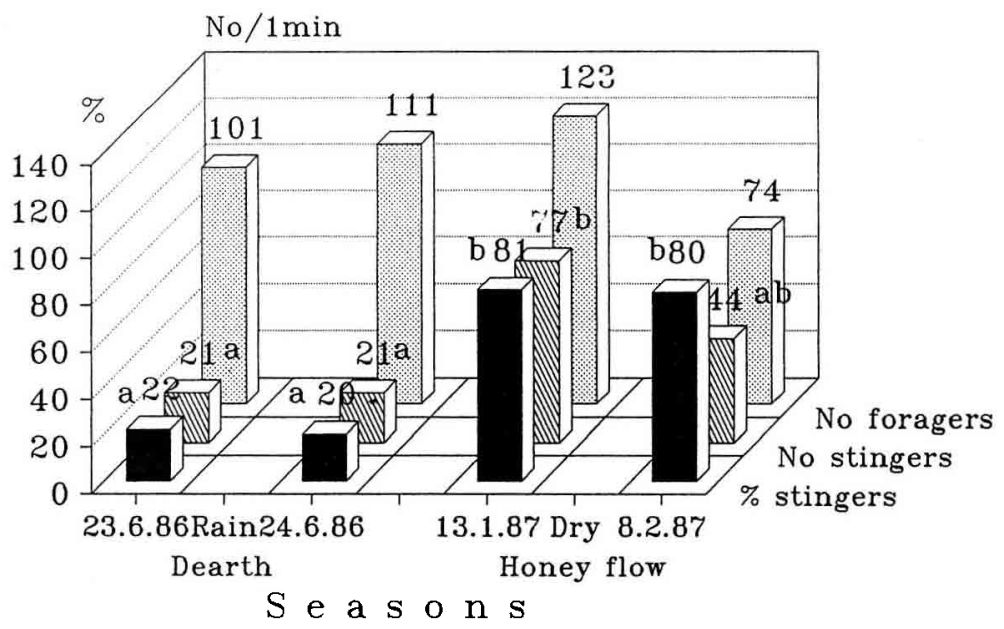

Fig 6. Defense behavior of colony No 4 during different seasons. Numbers above bars represent averages of 13 counts taken throughout the day. Different letters before or after the numbers indicate significant differences between the means (The $y$ units represent numbers of foragers and stinging bees and percentages indicate \% of stinging bees). 
quency distribution of the average numbers of stinging bees on both summer days and on February 8 (21, 21 and 44 respectively) differed significantly from the 1:1:1 distribution: $\chi^{2}$ calc $=12.30>\chi^{2}$ tab 0.05 $=5.99, P=0.02(\mathrm{df}=2)$. The ratio $(\%)$ of stinging bees to foragers did not differ within the same season; however, it was significantly higher on both days during the honey flow season than during the nonproductive period. Since the ratio amounted to $20-22 \%$ in summer and $80-81 \%$ in winter, this indicates that the defensive behavior of the same colony on the days of the investigation was about 4 times higher during the honey flow season than during the non-productive season. Thus the ratio of stinging bees to foragers does not remain constant throughout the year.

\section{Comparison of defensive behavior in 4 bee colonies}

Figure 7 shows that differences exist in the diurnal defensive behavior of different bee colonies. The pattern of defensive behav-

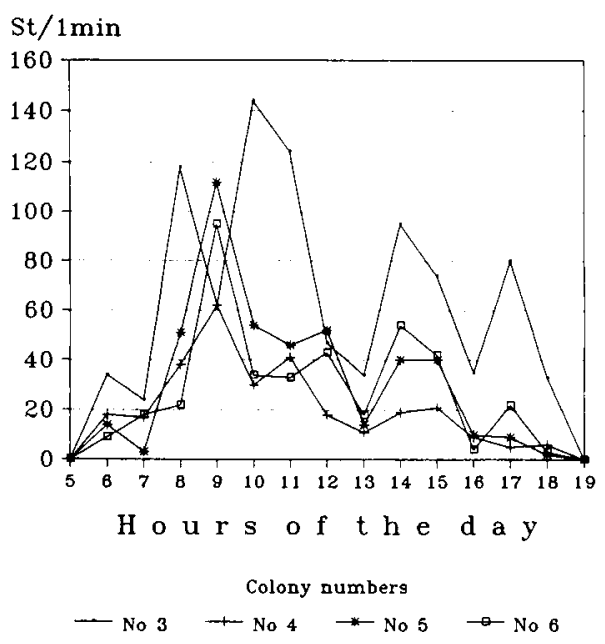

Fig 7. Diurnal defensive behavior of 4 bee colonies in Kumasi on June 23, 1986. ior in 3 colonies was similar. The morning peak of the 4th colony, No 3, occurred later (June 23). The next day the pattern was similar, but the peaks of the same colonies shifted as a function of time in comparison to the other colonies. The variation in defensive behavior between different colonies was statistically significant for both days.

The differences in the mean numbers of stings left in the test ball on June 23 were found to be statistically significant only between 1 colony and the 3 others (table I). The next day, differences between 3 colonies were found to be significant. After means for both days had been calculated, significant differences were only found between 2 colonies (table I): colony No 3 exhibited the most defensive, and No 4 the least defensive behavior.

\section{Ratio of stinging bees to foragers in 4 colonies}

A high correlation was found to exist between flight activity and stinging in colony No 4 . Flight activity of 4 bee colonies was therefore investigated at 10,11, 12, 14 and $15 \mathrm{~h}$. The relationship between average

Table I. Comparison of mean number of stings/ min left in a leather ball by 4 bee colonies during the entire day (13 repetitions between 6 and $18 \mathrm{~h})$.

\begin{tabular}{lllll}
\hline \multirow{2}{*}{ Date } & \multicolumn{5}{c}{ Colony No } \\
\cline { 2 - 5 } & 3 & 4 & 5 & 6 \\
\hline & & & & \\
\hline & & & \\
$24 / 6 / 1986$ & $70^{\mathrm{b}}$ & $23^{\mathrm{a}}$ & $34^{\mathrm{a}}$ & $31^{\mathrm{a}}$ \\
Both days & $66^{\mathrm{c}}$ & $21^{\mathrm{a}}$ & $38^{\mathrm{ab}}$ & $42^{\mathrm{b}}$ \\
& & $22^{\mathrm{a}}$ & $36^{\mathrm{b}}$ & $36^{\mathrm{b}}$ \\
\hline
\end{tabular}

- Different letters indicate significant differences between means of the same day: $P<0.05$. 
flight activity and colony defense was calculated (fig 8) and a statistical calculation was carried out.

At the time of the investigation, 11,10 and 8 brood combs containing 31.0, 39.9 and 33.8 thousand brood cells were found in colonies Nos 3, 4 and 5 respectively. The worker bees covered 4 more combs. The brood in colony No 6 was not measured. $\chi^{2}$-Test showed that the distribution of the average number of foragers from various colonies (fig 8 ) differed significantly from that of the number of combs presented above: $\chi^{2}$ calc $=8.12>\chi^{2}$ tab $0.05=$ $5.99, P=0.018$ (df $=2$ ), as well as from the number of brood cells: $\chi^{2}$ calc $=6.76>$ $\chi^{2}$ tab $0.05=5.99, P=0.035(\mathrm{df}=2)$. Thus the number of foragers was not correlated either with the number of brood combs or with the number of brood cells in these colonies.

Significant differences were found in the flight activity of different colonies (table Ii). Colony No 6 was significantly more active in foraging than both Nos 3 and 5 . Averag- es for stinging during the same period (10$15 \mathrm{~h}$ ) showed that bees in colony No 3 stung significantly more than all 3 (June, 23) or 2 other (Nos 4 and 5) colonies (June, 24). Workers in colony No 4 stung significantly less than both Nos 3 and 6 (June, 24). Thus the most active foragers (Nos 4 and 6) were not the most defensive bees, and the less active foragers (No 5) did not defend the colony less. The ratio of the number of stinging bees to the number returning to the hive varied considerably. According to the absolute number of stinging bees (table II; June, 24), no significant differences were found between colonies Nos 4 and 5 and between Nos 3 and 6; however, significant differences were found between those colonies in the ratio of stinging bees. Averages for both days are presented in figure $8 . \chi^{2}$-Test showed that the number of stinging bees in colonies Nos 5 and 6 did not differ significantly: $\chi^{2}=0.73, P=0.39(\mathrm{df}=1)$. However, the ratio of stinging bees in these colonies differed significantly: $\chi^{2}=13.30, P=0.00$ $(\mathrm{df}=1)$. Statistical calculations did not show

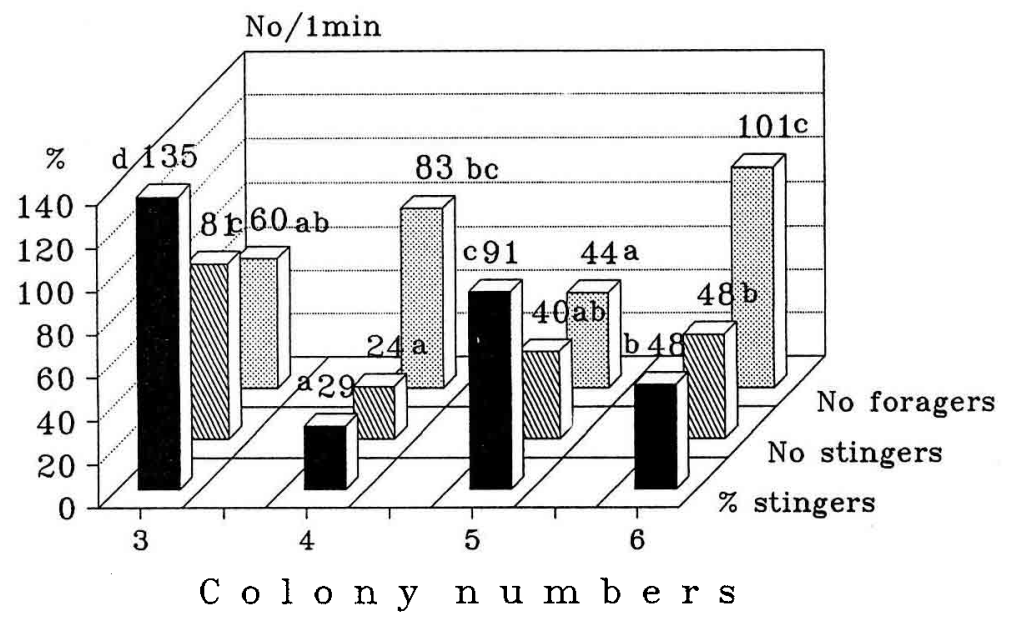

Fig 8. Comparison of the ratio of the number of stinging bees to foragers in 4 bee colonies in Kumasi; averages for June 23 and 24, 1986. Numbers above bars represent averages for 5 hourly counts conducted each day between 10 and $15 \mathrm{~h}$ (for further explanations see fig 6 ). 
Table II. Relationship between average number of foraging and stinging bees in different colonies (5 repetitions between 10 and $15 \mathrm{~h}$ ).

\begin{tabular}{|c|c|c|c|c|c|}
\hline \multirow[t]{2}{*}{ Colony No } & \multirow{2}{*}{$\begin{array}{c}\text { Avg No } \\
\text { foragers (min) }\end{array}$} & \multicolumn{2}{|c|}{ Stinging bees $23 / 6 / 86$} & \multicolumn{2}{|c|}{ Stinging bees $24 / 6 / 86$} \\
\hline & & $\mathrm{No} / \mathrm{min}$ & $\%$ & $\mathrm{No} / \mathrm{min}$ & $\%$ \\
\hline 3 & $60^{a b^{*}}$ & $97^{\mathrm{b}}$ & $192^{b}$ & $65^{c}$ & $114^{c}$ \\
\hline 4 & $83^{\text {bc }}$ & $26^{a}$ & $31^{a}$ & $22^{a}$ & $26^{a}$ \\
\hline 5 & $44^{a}$ & $46^{a}$ & $107^{a b}$ & $34^{\mathrm{ab}}$ & $79 \mathrm{bc}$ \\
\hline 6 & $101^{\mathrm{c}}$ & $41^{a}$ & $41^{\mathrm{a}}$ & $54^{b c}$ & $52^{\mathrm{ab}}$ \\
\hline
\end{tabular}

- Different letters indicate significant differences between means $P<0.05$.

a significant difference between average number of stinging bees in colonies Nos 4 and 5 . However, the ratio of stinging bees to foragers in these colonies differed significantly (fig 8). These results suggest that the ratio of the number of stinging to the number of foraging bees over the same period of time could be used as a better indicator for a comparison of potential defensive behavior in different colonies than the absolute number of stings left in a test ball.

\section{Practical application}

At the onset, examination of the bee colonies was conducted with the examiner fully protected with bee veil and leather gloves. The gloves had cuffs turned down with the rough leather outside. This irritated the bees considerably, and stimulated them to sting. Quite a lot of smoke was used. Colony No 4 was examined second after another colony in this apiary was checked. However, it defended itself so vigorously that it was impossible to examine all the combs. Some time later, when gloves were not used and only a little smoke was applied, it was possible to examine that colony without any protection and wearing only a short-sleeved shirt. After the results of this investigation showed that smoke irritated the bees, the author examined the col-ony without using any smoke, without any protection and without a shirt. Twenty combs were taken out of the hive and were lifted one by one to face height. The examiner was only stung once in the thorax during this operation. Many colonies were subsequently examined in the same manner. In the presence of the beekeepers, the author opened hives and removed combs without using protection or smoke at different apiary sites in Ghana, such as Tamale in the north, Nkoronza, Sampa and Boabeng-Fiema in the central region and Accra and Winneba in the south. When more laborious manipulations are involved, eg finding a queen, the use of a little smoke in recommended. However, the smoke should not be directed inside the colony, either through the entrance or between the top bars. It should be applied outside to keep the bees inside the hives. The management technique for African bees should differ from that for European bees. 


\section{DISCUSSION}

The purpose of this investigation was not to accurately characterize the defensive behavior of the $A \boldsymbol{m}$ adansonii population, or the seasonal variation in colony defense. The aim was to determine whether the practical observations had some scientific confirmation.

The defensive behavior of a bee colony throughout an entire day has not been investigated previously. It was not common knowledge that colony defense alters during the course of the day. Consequently, an account of the diurnal pattern of defense behavior has not been presented till now. In published papers, the hours of investigation have generally not been included, or conclusions have been drawn based upon comparisons conducted at different hours.

The results are too limited to characterize defensive behavior throughout both seasons. However, the results clearly show that the defensive behavior of the same colony did not remain constant, and differed significantly in different seasons. The pattern of diurnal colony defense, as well as the ratio of stinging bees to foragers, did not differ within the same season; however, it differed significantly between seasons. Certain facts suggest that the conclusions should not be limited only to the days of observation. Colony defense on both days during the honey flow season was similar, although observations were conducted at an interval of about 1 month. Observations on flight activity conducted by Woyke (1992) in Ghana over a 10-day period showed 2 distinct patterns of flight activity, one characteristic for the dearth period and the other for the honey flow season. Because a high correlation was found between flight activity and defensive behavior, it is suggested that 2 pat- terns of colony defense, characteristic for each season, may exist. The results presented here agree well with the general observation that bees defend the colonies much more vigorously during the honey flow season than during the dearth period - summer rainy season.

To compare defensive behavior of colonies of unequal strength, Collins and Kubasek (1982) equalized them so that each consisted of $900 \mathrm{~g}$ of bees. Villa (1988) equalized the colonies several times by removing sealed brood from the strongest colonies. Although these measures were of interest, they involved much trouble and did not assure the same number of flying bees. Another possibility has been presented here with the calculation of the ratio between foragers and stinging bees. The correlation between colony defense and flight activity was not calculated until Woyke presented his preliminary findings (1989) The 4 steps of colony defense proposed by Collins et al (1980) could not be investigated during this study, because the worker bees attacked the leather ball immediately after it had been suspended in front of the hive entrance.

\section{CONCLUSIONS}

A wide variation was observed in diurnal defensive behavior. A typical pattern of diurnal defensive behavior was found to exist. A high positive correlation existed between flight activity and defensive behavior. The bees stung less during the period of low flight activity. The pattern of defensive behavior was very different during the non-productive and the honey flow season respectively. The defense behavior within each season was similar; however, it differed between seasons. During the honey flow-winter dry season, the bees 
stung about 4 times more than during the non-productive-summer rainy season. Bees in front of the entrance to the hive defended the colony more vigorously than those that flew out from the combs. The smoke irritated the bees, resulting in more active defensive behavior. Significant differences existed in defensive behavior between different bee colonies. The ratio of the number of stinging bees to that of the flying bees appears to be a better indicator for comparison of potential defensive behavior of different bee colonies than the absolute number of stings. It is recommended that a comparison be made of defensive behavior of different bee colonies at the same period of time. For practical beekeepers, it is recommended that work with Apis mellifera adansonii be carried out during periods of low flight activity.

Résumé - Variation journalière et saisonnière du comportement de défense de l'abeille africaine Apis mellifera adansonii au Ghana. Nous avons étudié le comportement de défense de la colonie par l'abeille africaine, Apis mellifera adansonii, afin de formuler des recommandations pour les manipuler (quand, comment) en évitant d'être piqué. Une balle en cuir de couleur sombre a été suspendue pendant $1 \mathrm{~min} 50$ devant l'entrée ou à $25 \mathrm{~cm}$ au-dessus des barrettes de 2 passages ouverts entre les cadres. On a compté le nombre de piqûres faites dans la balle, ainsi que le nombre d'ouvrières rentrant à la ruche durant $5 \mathrm{~min}$. Les 2 comptages ont été effectués chaque heure, 13 fois par jour. Les résultats montrent une forte variation du comportement défensif au cours de la journée. Il existe un schéma typique du comportement défensif diurne. Pendant la saison humide (été, période de disette), on observe un pic le matin (fig 1) et pendant la saison sèche (hiver, période de miellée), un pic tôt le matin et un autre tard le soir (fig 3). II existe une corrélation fortement positive entre l'activité de vol et le comportement défensif (figs $1-3$ ). Les abeilles piquent moins lorsque l'activité de vol est faible. Les abeilles devant l'entrée défendent plus la colonie que celles qui quittent les rayons (fig 3 ). Durant la saison sèche, les abeilles piquent en moyenne 4 fois plus que pendant la saison humide (fig 6). Le comportement de défense diurne varie d'une colonie à l'autre (fig 7 et tableau 1). Le pourcentage d'abeilles qui piquent par rapport aux abeilles qui volent est un meilleur indicateur pour comparer le comportement défensif potentiel de différentes colonies que le nombre absolu de piqûres (fig 8 et tableau II). On recommande de manipuler les colonies d'A $m$ adansonii lorsque l'activité de vol est faible.

Apis mellifera adansonii / comportement défensif / rythme d'activité / activité de vol / Ghana

Zusammenfassung - Tages- und Saisonvariation beim Verteidigungsverhalten afrikanischer Bienen (Apis mellifera adansonii) in Ghana. Das Verteidigungsverhalten der afrikanischen Biene $A$ mellifera adansonii wurde untersucht, um Empfehlungen $\mathrm{zu}$ entwickeln, wann und wie diese Bienen ohne die Gefahr übermäßiger Stiche bearbeitet werden können. Dunkle Lederbälle wurden $50 \mathrm{~cm}$ oberhalb des Fluglochs oder $25 \mathrm{~cm}$ oberhalb von zwei geöffneten Wabengassen für $1 \mathrm{~min}$ aufgehängt. Die Zahl der im Ball zurückgelassenen Stacheln wurde gezähit. Ebenso wurde die Zahl der während einer Zeitspanne von 5 min zum Volk zurückkehrenden Trachtbienen aufgezeichnet. Beide Zählungen wurden stündlich durchgeführt, 13 mal den ganzen Tag über. Die erzielten Resultate zeigten eine große Variabilität des Verteidigungsverhaltens im Tagesverlauf. Es bestehen typische Muster im tägli- 
chen Verlauf des Verteidigungsverhaltens. Während der trachtlosen Zeit zur sommerlichen Regenperiode wurde ein einziger Gipfel erhöhter Verteidigungsreaktion am Morgen beobachtet (Abb 1); zur Trachtzeit während der winterlichen Trockenperiode traten zwei Gipfel auf, einer zeitig am Morgen und der andere spät am Abend (Abb 3). Es besteht eine hohe positive Korrelation zwischen Flugaktivität und Verteidigungsbereitschaft (Abb 1, 2, 3). Während schwacher Flugaktivität stechen die Bienen weniger. Die Bienen vor dem Flugloch sind eher zur Verteidigung des Volkes geneigt als Bienen, die aus den Wabengassen des geöffneten Volkes auffliegen (Abb 3). Während der Tracht in der winterlichen Trockenzeit stechen die Bienen etwa vier mal mehr als während der Sommerregenzeit (Abb 6). Es besteht eine Variabilität im täglichen Verteidigungsverhalten zwischen verschiedenen Völkern (Abb 7, Tabelle 1). Der Prozentsatz stechender Bienen im Verhältnis zu den Flugbienen ist ein besseres Maß des Verteidigungspotentials eines Volkes als die absolute Zahl der Stiche (Abb 8, Tabelle II). Es wird emfohlen, mit Völkern von $A m$ adansonii zur Zeit geringer Flugaktivität zu arbeiten.

\section{Apis mellifera adansonii / Verteidi- gungsverhalten / Aktivitätrhythmus / Flugaktivität / Ghana}

\section{REFERENCES}

Brandenburgo MM, Gonçalves LS, Kerr WE (1977) Effects of Brazilian climatic conditions upon aggressiveness of Africanized colonies of honeybees. Cienc Cult (Sao Paulo) 29 , 255-280
Collins AM, Kubasek KO (1982) Field test of honey bee (Hymenoptera: Apidae) colony defensive behaviour. Ann Entomol Soc Am 75, 383-387

Collins AM, Rinderer TE, Tucker KW, Sylvester HA, Lackett JJ (1980) A model of honeybee defensive behaviour. J Apic Res 19, 224-231

Collins $A M$, Rinderer TE, Harbo JR, Bolten AB (1982) Colony defense by Africanized and European honey bees. Science 218, 72-74

Free JB (1961) The stimuli releasing the stinging response of honeybees. Anim Behav 9, 193-196

Stort AC (1970) Methodologia para o estudo da genetica da aggressividade de Apis mellifera. Congr Bras Apic 36-51

Stort AC (1974) Genetic study of the aggressiveness of two subspecies of Apis mellifera in Brazil. 1. Some tests to measure aggressiveness. J Apic Res 13, 32-38

Stort AC (1975) Genetic study of aggressiveness of two subspecies of Apis mellifera in Brazil. 5. Number of stings in the leather ball. $J$ Kans Entomol Soc 48, 381-387

Villa JD (1988) Defensive behavior of Africanized and European honeybees at two elevations in Columbia. J Apic Res 27, 141-145

Woyke J (1973) Experiences with Apis mellifera adansonii in Brazil and Poland. Apiacta 8, 115-116

Woyke J (1989a) Biology and management of African honeybees Apis mellifera adansonii in Africa. XXXII Int Apic Congr, Rio de Janejro, 44-47

Woyke $J(1989 b)$ Experiences with queen bees rearing and instrumental insemination of Apis mellifera adansonii in Ghana. XXXII Int Apic Congr, Rio de Janeiro, 61

Woyke J (1992) Diurnal flight activity of African bees Apis mellifera adansonii in different seasons and zones of Ghana. Apidologie 23, 107-117 